\title{
CONDICTIO CAUSA DATA CAUSA NON SECUTA JAKO PODSTAWA ŻĄDANIA ZWROTU ŚWIADCZENIA SPEŁNIONEGO W TRAKCIE TRWANIA ZWIAZZKU PARTNERSKIEGO - DOŚWIADCZENIA SĄDÓW SZKOCKICH
}

DOI: http://dx.doi.org/10.12775/TSP-W.2017.002

Data wpływu: 26.01.2017

Data akceptacji:15.05.2017

Streszczenie: Wzrastająca liczba związków o charakterze niemałżeńskim, nazywanych konkubinatami lub związkami partnerskimi, łączy się z koniecznością rozwiązywania coraz częstszych sporów dotyczących skutków ustania związku, w tym rozliczeń świadczeń spełnianych na rzecz drugiej strony w czasie jego trwania. Wobec braku regulacji ustawowej tej kwestii i wątpliwych perspektyw, aby, przynajmniej w nieodległej przyszłości, stan ten się zmienił, polskie sądy zmuszone są poszukiwać instrumentów prawnych rozwiązywania sporów na tym tle, z których, wydaje się, żaden nie uwzględnia w pełni złożonego i skomplikowanego charakteru relacji łączących strony takich związków. Z uwagi na ugruntowany już pogląd o niedopuszczalności stosowania, nawet per analogiam, przepisów dotyczących stosunków majątkowych wynikających z zawarcia małżeństwa, przyjmuje się, że charakter i skutki powiązań majątkowych powstałych w związku z faktycznym utrzymywaniem wspólnoty przez konkubentów należy oceniać na podstawie unormowań właściwych ze względu na rodzaj i treść tych stosunków.

* Marek Sobczyk - dr hab., prof. nadzw. UMK, adiunkt w Katedrze Prawa Rzymskiego i Kanonicznego, Wydział Prawa i Administracji, Uniwersytet Mikołaja Kopernika w Toruniu. 
Słowa kluczowe: związek partnerski; konkubinat; rozliczenia między konkubentami; condictio causa data causa non secuta; bezpodstawne wzbogacenie; orzecznictwo sądów szkockich.

Condictio causa data causa non secuta - settlements between cohabitants in the light of verdicts of Scots courts. Cohabitation understood as a relationship between two persons of the opposite or the same sex who are not married is not regulated in Polish Law. For this reason Polish courts often meet obstacles when they try to settle property disputes between ex-cohabitants, especially when one of the partners has made significant financial contribution to the property of another in expectation that they would get married or remain in their informal relationship for a long time (until death).

Keywords: cohabitation; settlements between cohabitants; condictio causa data causa non secuta; unjustified enrichment; verdicts of Scots courts.

La condictio causa data causa non secuta come fondamento giuridico per rimborso della prestazione fornita nel corso della convivenza - l'esperienza del giudice scozzese. La convivenza intesa come un'unione tra due persone del contrario o dello stesso sesso che non sono sposate non è regolata dalla legge polacca. Per questo motivo i giudici polacchi a volte incontrano ostacoli quando tentano di risolvere le controversie realtive alla proprietà tra ex conviventi, specialmente qualora uno dei partner abbia dato un contributo finanziario significativo alla patrimonio di un altro in attesa che si sposino o rimangano nella loro unione informale per un lungo periodo (fino alla morte). Spesso accade che il partner contribuisca all' acquisizione di una terra, una casa o alla costruzione di una casa che diventi la proprietà del suo partner e dopo la separazione cerca il rimborso. L'autore propone che uno degli strumenti giuridici utili per i giudici polacchi sia la condictio causa data causa non secuta la cui equivalente nel diritto polacco è il concetto della prestazione fornita per uno scopo non conseguito (art. $410 \mathrm{com} .2$ del codice civile polacco). Tuttavia, la questione in esame è controversa nella dottrina polacca. Il contributo presenta come il giudice scozzese utilizza la condictio causa data causa non secuta. In base alle osservazioni riguardanti i casi scozzesi, l'autore trarre alcune conclusioni che consentirebbero ai giudici polacchi di attuare efficacemente questo strumento giuridico.

Parola chiave: La condictio causa data causa non secuta; convivenza; l'esperienza del giudice scozzese.

I. Wzrastająca liczba związków o charakterze niemałżeńskim, nazywanych konkubinatami lub związkami partnerskimi ${ }^{1}$, łączy się z koniecznością rozwią-

${ }^{1}$ Według przeważającego poglądu konkubinat jest nieformalnym związkiem kobiety i mężczyzny, którzy nie zawarli ze sobą małżeństwa, lecz pozostają we wspólnym, stałym pożyciu analogicznym do pożycia małżonków. Nie ma jednak przeszkód prawnych ani przeszkód językowych 
zywania coraz częstszych sporów dotyczących skutków ustania związku, w tym rozliczeń świadczeń spełnianych na rzecz drugiej strony w czasie jego trwania. Wobec braku regulacji ustawowej tej kwestii i wątpliwych perspektyw aby, przynajmniej w nieodległej przyszłości, stan ten się zmienił, polskie sądy zmuszone są poszukiwać instrumentów prawnych rozwiązywania sporów na tym tle, z których, wydaje się, żaden nie uwzględnia w pełni złożonego i skomplikowanego charakteru relacji łączących strony takich związków. Z uwagi na ugruntowany już pogląd o niedopuszczalności stosowania, nawet per analogiam, przepisów dotyczących stosunków majątkowych wynikających z zawarcia małżeństwa², przyjmuje się, że charakter i skutki powiązań majątkowych powstałych w związku z faktycznym utrzymywaniem wspólnoty przez konkubentów należy oceniać na podstawie unormowań właściwych ze względu na rodzaj i treść tych stosunków ${ }^{3}$. W opublikowanym niedawno artykule poświęconym temu zagadnieniu ${ }^{4}$ przychyliłem się do poglądu, że jedną z potencjalnych podstaw prawnych rozliczeń stron może być art. 410 § 2 k.c., w części dotyczącej świadczenia

do używania tego terminu w celu oznaczenia nieformalnego związku osób tej samej płci. Do języka potocznego i języka prawniczego weszło w ostatnich latach określenie związek partnerski, którego zakres znaczeniowy obejmuje zarówno konkubinaty heteroseksualne, jak i faktyczne trwałe związki życiowe osób tej płci (J. Ignatowicz, M. Nazar, Prawo rodzinne, Warszawa 2012, s. 1050, por. M. Nazar, Konkubinat, [w:] System Prawa Prywatnego, t. 11, Prawo rodzinne i opiekuńcze, red. T. Smyczyński, Warszawa 2009, s. 909 i n.; A. Szlęzak, Stosunki majątkowe między konkubentami. Zagadnienia wybrane, Poznań 1992, s. 9 i n.). W orzecznictwie nadal często prezentowane jest tradycyjne stanowisko odnoszące termin konkubinat tylko do związków heteroseksualnych (zob. w szczególności wyrok SN z 06.12.2007 r., IV CSK 301/07, por. jednak odmienne stanowisko Sądu Apelacyjnego w Białymstoku w wyroku z 23.02.2007 r., I ACa 590/06 i Sądu Apelacyjnego w Warszawie w wyroku z 26.06.2014 r., I ACa 40/14). Zwykle też związek osób odmiennej płci określany jest terminem konkubinat, a rzadziej terminem związek partnerski. Niniejsze rozważania odnoszą się zarówno do związków heteroseksualnych, jak i homoseksualnych (por. rozumienie tych terminów w monografii F. Hartwicha, Związki partnerskie. Aspekty prawne, Warszawa 2011, passim oraz J. Pawliczak, Zarejestrowany zwiąek partnerski a małżenstwo, Warszawa 2014, s. 49 i n.).

2 Uchwała SN z 02.02.1955 r., II Co. $7 / 55$ (P); uchwała SN z 30.01.1970 r., III CZP 62/69; uchwała SN z 30.01.1986 r., III CZP 79/85; wyrok SN z 16.05.2000 r., IV CKN 32/00; postanowienie SN z 10.09.2009 r., V CSK 75/09; wyrok Sądu Apelacyjnego w Warszawie z 26.04.2011 r., I ACa 1049/10; wyrok Sądu Apelacyjnego w Szczecinie z 16.04.2014 r., I ACa 61/14; wyrok Sądu Apelacyjnego w Białymstoku z 12.06.2014 r., I ACa 601/13; M. Nazar, op. cit., s. 920; F. Hartwich, op. cit., s. 95 i n.

${ }^{3}$ Uchwała SN z 30.01.1986 r., III CZP 79/85; wyrok SN z 22.06.2007 r., V CSK 114/07; postanowienie SN z 10.09.2009 r., V CSK 75/09; wyrok Sądu Apelacyjnego w Szczecinie z 16.04.2014 r., I ACa 61/14; wyrok Sądu Apelacyjnego w Białymstoku z 6.06.2013 r., I ACa 203/13. Pogląd ten zyskał akceptację w doktrynie, zob. F. Hartwich, op. cit., s. 94 i n.

${ }^{4}$ Zob. Rozliczenia między stronami związków partnerskich na podstawie przepisów o bezpodstawnym wzbogaceniu, „Kwartalnik Prawa Prywatnego” 2015, nr 2, s. 381-408. 
w zamierzonym celu, który nie został osiągnięty, co odpowiada ugruntowanej w teorii prawa prywatnego, sięgającej korzeniami prawa rzymskiego, koncepcji nazywanej condictio ob rem lub condictio causa data causa non secuta ${ }^{5}$. Dopuszczalność zastosowania condictio causa data causa non secuta do rozliczeń związków partnerskich jest jednak w polskiej doktrynie prawa nadal bardzo kontrowersyjna ${ }^{6}$. Ze stanowczym sprzeciwem spotkało się zwłaszcza twierdzenie, że celem świadczenia może być pozostawanie stron w związku, gdyż po pierwsze, „konkubinat nie jest instytucją prawną, a więc nie może być «generalnie» normowany jakimikolwiek normami prawnymi. Po drugie, nadzieja czy oczekiwania (nawet znane drugiej stronie) jednego z konkubentów pozbawione są jakiegokolwiek prawnego znaczenia”. Ponadto podnosi się, że konkubinat „może być zerwany bez prawnych konsekwencji w każdym czasie przez każdego z konkubentów”, a także, że „czynność prawna zobowiązująca do zachowania jego trwałości (w dodatku w zamian za określone świadczenia majątkowe) jako sprzeczna z prawem okazałaby się nieważna"7.

$\mathrm{Z}$ uwagi na tę krytykę postanowiłem prześledzić, w jaki sposób condictio causa data causa non secuta jest wykorzystywana jako podstawa zwrotu świadczenia w obcych systemach prawnych. Okazało się, że interesujących porównań dostarcza orzecznictwo wydawałoby się dość odległego jurydycznie systemu prawnego, jakim jest system szkocki ${ }^{8}$, w którym jeszcze do niedawna kondykcja ta stanowiła najważniejszą podstawę prawną żądań zwrotu wzbogacenia, z jakimi zubożeni występowali wobec byłych swych partnerów po ustaniu związku. Regulacja ustawowa tej materii, Family Law (Scotland) Act, pojawiła się dopiero w 2006 r. i zasadniczo wyparła, choć okazuje się, że nie do końca, wzmian-

${ }^{5}$ Obie te nazwy określają w istocie tę samą figurę condictio, przy czym druga z nich została w tytule Digestów Justyniana zawierającym fragmenty dzieł jurystów poświęcone temu zagadnienie (D.12.4 De condictione causa data causa non secuta). Co interesujące, opracowany niemal w tym samym czasie Kodeks Justyniana posługuje się nazwą condictio ob causam datorum (C.4.6).

${ }^{6}$ Zob. zwłaszcza T. Sokołowski, Kodeks cywilny, Komentarz, red. A. Kidyba, Warszawa 2014, uwaga 8 do art. 410 .

${ }^{7}$ K. Mularski, Kodeks cywilny, t. 1., Komentarz do art. 1-449 $9^{11}$, red. M. Gutowski, Warszawa 2016, uwaga 15 do art. 410.

${ }^{8}$ Szkockie prawo prywatne jest jednym z podstawowych przykładów tzw. mieszanych systemów prawnych, zawierających komponenty zarówno civil law, jak i common law. Akurat bezpodstawne wzbogacenie oparte jest na zasadach właściwych dla civil law, choć dostrzegalny jest w nim pewien wpływ common law, por. H. MacQeen, Payment of Another's Debt, [in:] Unjustified Enrichment: Key Issues in Comparative Perspective, eds. R. Zimmermann and D. Johnston, Cambridge 2002, s. 462 i n.; N. R. Whitty, Rationality, Nationality and the Taxonomy of Unjustified Enrichment, [in:] Unjustified Enrichment:..., op. cit., s. 658 i n. 
kowaną kondykcję ${ }^{9}$ Przedstawione poniżej sprawy przede wszystkim stanowią dowód na to, że kondykcja ta w ogóle może stanowić podstawę prawną zwrotu świadczenia spełnionego przez partnera, a nadto ilustrują problemy prawne, jakie w praktyce przynosi jej stosowanie, dlatego analiza argumentacji sądów stanowi ważki i interesujący punkt odniesienia dla podobnych spraw rozstrzyganych przez polskie sądy. Dopóki związki partnerskie nie doczekają się w Polsce regulacji ustawowej, zawarta $w$ art. $410 \S 2$ k.c.. koncepcja celu świadczenia, który nie został osiągnięty będzie stanowić jedną z podstaw prawnych rozstrzygnięć sądów, warto więc zapoznać się z doświadczeniem szkockim.

II. Najważniejszą ze spraw, często przywoływaną w późniejszym orzecznictwie, jest sprawa Shilliday v Smith ${ }^{10}$ rozstrzygnięta w 1998 r. Powódka żądała w niej zwrotu świadczeń, które spełniła pozostając w nieformalnym związku z pozwanym, w okresie, w którym strony żyły z sobą ,jak mąż i żona” i planowały zawarcie związku małżeńskiego, a nawet zdążyły się zaręczyć. Ich przedmiotem był wkład finansowy w remont domu, który nabył pozwany, a który miał być ich „domem małżeńskim”. Uzasadniając żądanie powódka podnosiła, że współfinansowała remont pod warunkiem (on condition) zawarcia planowanego związku małżeńskiego, do czego jednak nie doszło, ponieważ związek stron rozpadł się.

Szkocki Sąd Najwyższy w sprawach cywilnych (Court of Session) oddalając apelację pozwanego od korzystnego dla powódki wyroku, nieco inaczej zakwalifikował prawnie żądanie powódki, przesuwając akcent z „warunku” na bezpodstawne wzbogacenie ${ }^{11}$. W zgodnej opinii Lordów ${ }^{12}$ żądanie powódki stanowi bowiem roszczenie z tytułu bezpodstawnego wzbogacenia, co zostało umotywowane $\mathrm{z}$ dość szerokim odniesieniem do istoty samej instytucji bezpodstawnego wzbogacenia i z przywołaniem najistotniejszych prac jej poświęconych (zwłaszcza ówcześnie największego autorytetu w tej sferze Petera Birksa $\left.{ }^{13}\right)$. W ten spo-

9 Na temat tej regulacji por. J. Pawliczak, Szkocki model regulacji konkubinatu, ,Kwartalnik Prawa Prywatnego" 2010, z. 3, s. 695-716.

101998 SC 725, 1998 SLT 976.

${ }^{11}$ Gdyby ta sprawa była rozstrzygana według common law w rachubę wchodziłaby jeszcze konstrukcja nazywana constructive trust, jednakże szkockie prawo rzeczowe oparte jest na zasadach właściwych dla civil law, zob. D.L. Carey Miller, M.M. Combe, The Boundaries of Property Rights in Scots Law, Report to the XVIIth International Congress of Comparative Law, July 2006, „Electronic Journal of Comparative Law” 2006, vol. 10.3, www.ejcl.org, s. 9.

12 Pisemną i samodzielną opinię przedstawił każdy z Lordów rozpoznających sprawę (odrębne opinie Lordów, stanowiące w istocie samodzielne wyroki, są cechą specyficzną wyrokowania w Court of Session). Opinie te były zgodne co do zasadniczych aspektów faktycznych i prawnych sprawy.

${ }_{13}$ Profesor prawa cywilnego (Regius Professor) na Uniwersytecie w Oxfordzie. Jeden z naj- 
sób w sprawie tej Sąd syntetycznie przedstawili współczesną koncepcję bezpodstawnego wzbogacenia w Szkocji ${ }^{14}$.

W najszerzej umotywowanej z trzech sporządzonych opinii Lord Prezydent Roger przychylił się do koncepcji, że bezpodstawnie wzbogaconą cudzym kosztem jest osoba, która uzyskała korzyść (benefit) z działań lub wydatków (actings or expenditure) innej osoby w sytuacji, w której nie zachodzi podstawa usprawiedliwiająca zachowanie tej korzyści przez wzbogaconego ${ }^{15}$. W toku swego rozwoju prawo szkockie wypracowało kilka kategorii sytuacji, w których uważa się, że doszło do tak rozumianego bezpodstawnego wzbogacenia. Lord Prezydent uznał, że korespondują one, aczkolwiek luźno, z rzymskimi condictiones, zwłaszcza condictio indebiti, condictio causa data causa non secuta, a w mniejszym stopniu także condictio sine causa. Zauważył także, że terminologia Digestów i Kodeksu Justyniańskiego pozostaje nadal w użyciu w prawie szkockim $^{16}$. Okoliczności rozpoznawanej sprawy odpowiadają condictio causa data causa non secuta, której istotę Lord Prezydent wyłożył stwierdzając, że odnosi się ona do sytuacji, w której osoba A wzbogaciła się, ponieważ osoba B zapłaciła jej pieniądze lub przeniosła na nią prawo własności rzeczy w oczekiwaniu na świadczenie wzajemne (consideration), którego jednak osoba A nie spełniła. Poza tym condictio ta ma zastosowanie w sytuacji, w której osoba B spełniła świadczenie na rzecz osoby A na określonej podstawie, która się nie urzeczywistniła (on a particular basis which fails to materialize), np. na poczet planowanego w przyszłości małżeństwa, które ostatecznie nie zostało zawarte.

większych, jeśli nie największy z autorytetów z zakresu problematyki restitution w common law, do której wniósł znaczny wkład, wywierając spory wpływ na rozstrzygnięcia sądów i współczesną teoretyczną koncepcję tej instytucji. Interesował się także prawem szkockim i regulacją bezpodstawnego wzbogacenia w systemach kontynentalnych.

${ }_{14}$ Argumentacja sądu stanowiła asumpt do podjęcia w doktrynie szerokiej dyskusji na temat szkockiej koncepcji bezpodstawnego wzbogacenia, a zwłaszcza wyboru, czy pozostać przy jej kontynentalnej, czy też w większym stopniu czerpać z dorobku common law. Zob. J. Wolffe, Enrichment by Improvements in Scots Law, [in:] Unjustified Enrichment:..., op. cit., s. 384 i n.; J. du Plessis, Towards a Rational Structure of Liability for Unjustified Enrichment: Thoughts from Two Mixes Jurisdiction [in:] Grundstrukturen eines Bereicherungsrechts, ed. R. Zimmermann, Tübingen 2005, s. 175-219 z przywołaną tam literaturą. W niniejszym opracowaniu ograniczam się jedynie do wątków bezpośrednio związanych z tematem i zarazem takich, które można porównać do koncepcji kontynentalnych, dlatego pomijam w szczególności problem tzw. remedies.

15 Jest to koncepcja wyrażona przez Lorda Cullena w sprawie Dollar Land (Cumbernauld) Ltd. v. CIN Properties Ltd. 1996 S.C. 331.

${ }^{16}$ Szerzej na temat terminologii zob. M.A. Hogg, Lowlands to Low Country. Perspectives on the Scottish and Dutch Law of Unjustified Enrichment, "Ius Commune Lectures on European Private Law" 2001, nr 3, pkt 2.2. 
Uściślając powyższe ogólne wywody trzej opiniujący sprawę Lordowie zgodnie przywołali passus Instytucji uważanego za ojca prawa szkockiego siedemnastowiecznego prawnika, swego czasu Lorda Prezydenta Court of Session, Jamesa Dalrymple Pierwszego Wicehrabiego Staira $(1.7 .7)^{17}$, który to passus z uwagi na jednoznaczność przywołanego w nim przykładu stał się zasadniczą podstawą rozstrzygnięcia:

The duty of restitution extendeth to those things, quae cadunt in non causam, which coming warrantably to our hands and without any paction of restitution, yet if the cause cease by which they become ours, there superveneth the obligation of restitution of them. Whence are the condictions in law, sine causa and causa data causa non secuta, which have this natural ground; and of which there are innumerable instances. As all things that become in the possession of either party in contemplation of marriage, the marriage (which is the cause) failing to be accomplished, the interest of either party ceaseth, and either must restore.

Stair, stwierdza w nim, że zwrot (restitution) odnosi się do rzeczy quae cadunt in non causam i nie wymaga żadnego uzgodnienia (paction), jeżeli ustała causa, ze względu na którą stały się nasze. We fragmencie tym wzmiankowane są dwie kondykcje sine causa i causa data causa non secuta, które mają naturalną podstawę (natural ground) ${ }^{18}$. Stair nie wnika w istotę tych kondykcji, jednakże ilustrując drugą z nich podaje właśnie przykład świadczenia spełnionego w oczekiwaniu zawarcia małżeństwa (in contemplation of marriage), które nie doszło do skutku.

Dokonując interpretacji tego fragmentu Lord Prezydent stwierdził, że w sytuacji określonej jako sine causa ktoś uzyskuje korzyść majątkową na określonej podstawie, która później przestaje istnieć, natomiast w sytuacji opisanej jako causa data causa non secuta ktoś uzyskuje taką korzyść z uwagi na określone przyszłe zdarzenie, które nie zdołało się urzeczywistnić (on the basis of some future event which fails to materialize). W obu przypadkach obowiązek zwrotu nie wynika z kontraktu, lecz z naturalnej podstawy, co oznacza, że stanowi obowiązek nakładany przez samo prawo. Lordowie zgodnie podkreślili, że roszczenie powódki nie ma natury kontraktowej, nie wynika z żadnej zawartej umowy, zaś zawarcie małżeństwa nie stanowiło warunku (condition), pod którym dokony-

17 Pierwsze drukowane wydanie Institutions of the Law of Scotland Deduced from its Originals, and Collated with the Civil, Canon, and Feudal-Laws; and with the Customs of Neighbouring nations Staira ukazało się w $1681 \mathrm{r}$.

${ }^{18}$ Chodzi w tym miejscu o wyróżnioną przez Staira kategorię obedential obligations. 
wała ona płatności, lecz okoliczność ze względu, na którą je dokonała ${ }^{19}$. Court of Session stanowczo odróżnił świadczenia, które następują on condition that od tych, które następują in contemplation of, stwierdzając, że to pierwsze sformułowanie sugeruje zawarcie kontraktu. W rozpoznawanej sprawie świadczenia nie nastąpiły „,pod warunkiem”, dlatego powódka nie miała obowiązku wykazania zawarcia żadnego kontraktu. Z tego względu zamiast użytego przez powódkę sformułowania on condition that they will get married, należało uznać, że jej świadczenia następowały in contemplation of their marriage.

Argumentacja zawarta w opiniach Lordów rozpoznających sprawę, wywodzona z cytowanego fragmentu Instytucji Staira odpowiada, przynajmniej co do istoty, koncepcji określanej rzymskim mianem condictio causa data causa non secuta, która w języku prawnym kodeksów kontynentalnych przybrała postać świadczenia w zamierzonym celu, który nie został osiągnięty ${ }^{20}$. Kondykcja ta ma bowiem zastosowanie w przypadkach, w których jedna osoba spełniła na rzecz drugiej świadczenie, nie będąc do tego zobowiązana na mocy umowy, lecz kierując się przyszłym rezultatem lub stanem rzeczy, którego osiągnięcia oczekiwała $^{21}$. Cel świadczenia może być w zasadzie dowolnym dozwolonym przyszłym stanem faktycznym ${ }^{22}$, w szczególności może odnosić się do określonego zachowania odbiorcy świadczenia, choć po jego stronie nie leży prawny obowiązek podjęcia tego zachowania, jednakże jeżeli uczyni to ma prawo zachować otrzymane świadczenie ${ }^{23}$. Cel świadczenia jest przy tym objęty tzw. porozumieniem

${ }^{19}$ Lord Prezydent uznał, że sformułowanie, iż świadczenia nastąpiły pod warunkiem zawarcia małżeństwa sugeruje, iż strony zawarły jakaś umowę, dlatego właściwszym jest uznanie, że świadczenia nastąiły in contemplation of marriage.

${ }^{20}$ Zob. art. $410 \S 2$ k.c., por. $§ 1435$ austriackiego kodeksu cywilnego, $\S 812$ ust. 1 zd. 2 niemieckiego kodeksu cywilnego, art. 62 ust. 2 szwajcarskiego kodeksu zobowiązań, art. 129 kodeksu zobowiązań z 1933 r.

${ }^{21}$ Na temat tej kondykcji w prawie polskim zob. w szczególności: A. Ohanowicz, Niestuszne wzbogacenie (1956), [w:] A. Ohanowicz, Wybór prac, red. A. Gulczyński, Warszawa 2007, s. 836 i n; Idem, Bezpodstawne wzbogacenie (1981), [w:] A. Ohanowicz, Wybór prac, red. A. Gulczyński, Warszawa 2007, s. 1031 i n.; W. Serda, Nienależne świadczenie, Warszawa 1988, s. 94 i n.; E. Lętowska, Bezpodstawne wzbogacenie, Warszawa 2000, s. 98 i n.; P. Księżak, Bezpodstawne wzbogacenie. Art. 405-414 KC. Komentarz, Warszawa 2007, s. 191 i n.: Idem, Kodeks cywilny. Komentarz, red. K. Osajda, Warszawa 2016, uwaga 77 i n. do art. 410; W. Dubis, Kodeks cywilny. Komentarz, pod E. Gniewek, Warszawa 2016, uwaga 12 i n. do art. 410; K. Mularski, nb. 12 i n. do art. 410; R. Trzaskowski, Kodeks cywilny. Komentarz, red. J. Gudowski, Warszawa 2013, uwaga 18 i n. do art. 410; P. Mostowik, Bezpodstawne wzbogacenie, [w:] System Prawa Prywatnego, t. 6. Zobowiazania. Część ogólna, Warszawa 2009, s. 306 i n. W orzecznictwie SN zob. zwłaszcza wyroki z: 17.01.2002 r., III CKN 1500/00; 21.06.2011 r., I CSK 533/10; 13.10.2011 r., V CSK 483/10: 15.04.2015 r., IV CSK 456/14; 21.04.2016 r., III CNP 18/15.

${ }^{22}$ P. Księżak, Bezpodstawne, op. cit., s. 191; Idem, Kodeks, op. cit., uwaga 77.

${ }^{23}$ Aspekt ten jest wielokrotnie podkreślany w orzecznictwie, w szczególności uważa się, że 
co do podstawy świadczenia, które choć nie jest czynnością prawną, stanowi sui generis uzgodnienie stron ${ }^{24}$, albowiem cel ten musi być wspólny lub co najmniej określony przez świadczącego i znany lub rozpoznawalny dla przyjmującego świadczenie ${ }^{25}$. Świadczenie spełnione ze względu na małżeństwo, które ma zostać w przyszłości zawarte jest podstawowym przykładem zastosowania tej kondykcji ${ }^{26}$. Szkocki sąd tym samym zastosował podstawę prawną typową dla orzecznictwa civil law. Warto w tym miejscu zauważyć, że argumentacja Lordów ujawnia podstawową różnicę pomiędzy nieskodyfikowanym prawem szkockim i prawami kontynentalnymi, trudno bowiem sobie wyobrazić, aby podstawą wyroku kontynentalnego sądu był jedynie pogląd prawny, choćby nawet najznakomitszego prawnika. W ustawodawstwach kontynentalnych rzymskie condictiones zostały przekute na język przepisów prawa i tylko znajomość koncepcji teoretycznych kryjącej się za treścią tych przepisów pozwala ustalić, do której z rzymskich kondykcji odnosi się konkretny przepis. Łacińskie nazwy kondykcji funkcjonują nadal w języku prawniczym, choć ich obecna treść stanowi rezultat wielowiekowej ewolucji, w której można dostrzec zarówno rzymski rdzeń, jak i sporo zmian i elementów dodanych w trakcie tej ewolucji.

Waga analizowanego rozstrzygnięcia wynika wszakże nie tylko z faktu oparcia go na koncepcji condictio causa data causa non secuta, ale także z wyraźnego stwierdzenia, że cel świadczenia nie ma natury kontraktowej ani nawet nie może mieć takiej natury, albowiem w przeciwnym razie do problemu zwrotu

przesłanka nieosiągnięcia zamierzonego celu świadczenia (art. $410 \S 2 \mathrm{KC}$ ) jest spełniona wtedy, gdy jego celem było otrzymanie świadczenia ekwiwalentnego, do spełnienia którego odbiorca nie był zobowiązany, zob. wyroki SN z: 17.01.2002 r., III CKN 1500/00; 15.04.2015 r., IV CSK 456/14; 21.04.2016 r., III CNP 18/15.

${ }^{24}$ Nazywane jest to ,porozumieniem woli”, zob. wyrok SN z 17.01.2002 r., III CKN 1500/00, wyrok SN z 12.01.2006 r., II CK 342/05, wyrok Sądu Apelacyjnego w Poznaniu z 6.06.2006 r., I ACa 131/06, podobnie ostatnio wyroki Sądu Apelacyjnego w Krakowie z 15.07.2014 r., I ACa 637/14 i z 21.04.2016 r., I ACa 1809/15 oraz wyrok Sądu Apelacyjnego w Gdańsku z 21.07.2016 r., V ACa 970/15.

${ }^{25}$ P. Księżak, Bezpodstawne wzbogacenie, op. cit., s. 193, Idem, Kodeks, uwaga 83 do art. 410; W. Serda, op. cit., s. 95 i n.; K. Kołakowski, Kodeks. cywilny. Komentarz, red. G. Bieniek, Warszawa 2011, uwaga 4 do art. 410; P. Księżak, Bezpodstawne wzbogacenie, s. 192 i n.; A. Rzetecka-Gil, Kodeks cywilny. Komentarz, Zobowiąania - część ogólna. Warszawa 2011, uwaga 25 i n. do art. 410; G. Karaszewski, Kodeks cywilny. Komentarz, red. J. Ciszewski, Warszawa 2014, uwaga 8 do art. 410; R. Trzaskowski, uwaga 20 do art. 410; W. Dubis, [w:] Kodeks, uwaga 1 do art. 410; P. Mostowik, Bezpodstawne wzbogacenie, [w:] System, s. 306; Idem, Bezpodstawne wzbogacenie, [w:] „Studia Prawa Prywatnego” 2007, z. 2(5), s. 85; K. Mularski, nb. 13 do art. 410.

${ }^{26}$ P. Księżak, Bezpodstawne wzbogacenie, op. cit., s. 196; Idem, Kodeks, uwaga 90 do art. 410; K. Kołakowski, uwaga 5 do art. 410; G. Karaszewski, uwaga 15 do art. 410; R. Trzaskowski, uwaga 22 do art. 410. Bardzo krytycznie o możliwości zastosowania zob. K. Mularski, nb. 15 do art. 410; T. Sokołowski, uwaga 8 do art. 410 . 
świadczenia zamiast bezpodstawnego wzbogacenia należałoby stosować reżim odpowiedzialności kontraktowej. Podobnie oparcie rozstrzygnięcia na reżimie bezpodstawnego wzbogacenia w miejsce koncepcji świadczenia spełnionego pod warunkiem zawarcia małżeństwa nie stanowi jedynie niezbędnej na płaszczyźnie teoretycznej korekty uzasadnienia roszczenia powódki, ale wywiera doniosłe skutki praktyczne. Otóż uznanie, że świadczenie nastąpiło w oczekiwaniu zawarcia małżeństwa, a nie pod warunkiem zawarcia małżeństwa istotnie ułatwia powodowi dochodzenie roszczenia, gdyż nie musi udowadniać, że strony zawarły jakąś umowę, w której zastrzeżony został warunek świadczenia, wystarczy, że powód wykaże, że w tych okolicznościach kierował się przekonaniem, że zostanie zawarte małżeństwo i ze względu na to zdecydował się przenieść korzyść majątkową na pozwanego, któremu taka motywacja powoda była znana, nawet jeżeli strony nie poczyniły wyraźnych ani tym bardziej sformalizowanych ustaleń co do takiego charakteru świadczenia.

III. Zasady wyłożone przez Lorda Prezydenta Rodgera w sprawie Shilliday v. Smith wyznaczyły sposób rozstrzygania podobnych spraw przez szkockie sądy. Ilustracją tego jest sprawa Moggach v. Milne, do której odnosi się wyrok Sheriff Principal $^{27}$ z 22 października $2004 \mathrm{r}^{28}$. W sprawie tej powód dochodził zwrotu wzbogacenia od swej byłej partnerki, które wywodził z tego, że wniósł swój finansowy wkład w zakup domu, który stał się jej wyłączną własnością, a następnie współfinansował remont tego domu, ponosząc ponadto nakład własnej pracy i czasu w prace remontowe. Powód podnosił, że uczynił to, ponieważ oczekiwał, iż dom zostanie nabyty w imieniu obojga partnerów (in joint names). Podkreślał także, że w żadnym razie nie miał zamiaru poczynić darowizny ani innego nieodpłatnego przysporzenia na rzecz pozwanej. Przed zakupem nieruchomości rozsądnie wierzył i przewidywał (reasonably believed and anticipated), że oboje nabędą tytuł do niej, jednakże to przekonanie było błędne. Pomimo jednak tego, że dom nie został nabyty w imieniu obojga partnerów, zdecydował się później poczynić znaczne nakłady środków, czasu i pracy na jego remont. W tym zakresie twierdził, że rozsądnie wierzył, że otrzyma udział stanowiący połowę w prawie własności tej nieruchomości, a jego przekonanie było oparte na trwającym związku stron i perspektywie ich przyszłego małżeństwa. Spór dotyczący własności nieruchomości stał się w końcu jedną z przyczyn rozpadu trwającego ok. 20 lat związku. Z argumentacji powoda wynikało także, że w chwili, w której wnosił swój wkład w zakup nieruchomości nie kierował się zamiarem zawarcia związku małżeńskiego, lecz przekonaniem, że zostanie ona nabyta w imieniu

27 Sheriff Principal jest sądem odwoławczym od orzeczeń sheriff courts.

${ }^{28}$ Sheriffdom of Grampian Higdland and Inlands at Elgin, A. 451/01. 
obojga partnerów. Roszczenie powoda opiewało na połowę aktualnej wartości domu, która zresztą znacznie wzrosła od chwili jego zakupu nie tylko z uwagi na remont, ale także z uwagi na ogólny trend wzrostu cen nieruchomości. Pozwana zaprzeczyła, że zakup nieruchomości miał nastąpić w imieniu obojga partnerów i że powód wniósł wkład w cenę nabycia lub w późniejszy remont domu. Podała wszakże, że strony uzgodniły, iż powód nabędzie udział w prawie własności nieruchomości dopiero po zawarciu małżeństwa. Zawarcie takie jednak rozważano dopiero kilka lat po nabyciu nieruchomości i było ono kilka razy przekładane, ponieważ powód ostatecznie nie decydował się na nie.

Odnosząc się do aspektu prawnego sprawy Sheriff Principal przywołał poglądy prawne wyrażone w sprawie Schilliday v. Smith. W przypadku przysporzenia korzyści innej osobie majątkowej Sheriff Principal nakazał poszukiwać czynnika (factor), który czyni wzbogacenie nieusprawiedliwionym (bezpodstawnym $)^{29}$. Zobowiązanie do zwrotu wzbogacenia powstaje bowiem z mocy prawa, ale tylko w sytuacji, w której ma miejsce czynnik, ze względu na który wzbogacenie jest bezpodstawne. W przypadku condictio causa data causa non secuta może nim być okoliczność, że jedna osoba przekazała innej pieniądze lub własność rzeczy w oczekiwaniu świadczenia wzajemnego (consideration), które nie nastąpiło lub na określonej podstawie, która się nie urzeczywistniła. Sąd podkreślił, że to na powodzie spoczywa ciężar dowodu wykazania, że wniósł finansowy wkład w zakup nieruchomości i jaka była wartość tego wkładu. Za wystarczającą okoliczność uzasadniającą zwrot wzbogacenia uznał, także pozostające do wykazania, oczekiwanie powoda, aby nieruchomość została nabyta w imieniu obojga partnerów, a po jej nabyciu wyłącznie przez pozwaną, że powód stanie się jej współwłaścicielem. Sam niespełniony zamiar zawarcia związku małżeńskiego pozostawał w tle, nie stanowił determinantu rozstrzygnięcia i nie był poddawany szczególnej weryfikacji. Była to raczej dodatkowa okoliczność uzasadniająca przekonanie powoda, że stanie się współwłaścicielem nieruchomości.

IV. W wyroku w sprawie Satchwell v McIntosh rozstrzygniętej w 2006 r. ${ }^{30}$ $\mathrm{w}$ istotnym zakresie rozszerzono możliwość posługiwania się condictio causa data causa non secuta. Tutaj także powód żądał zwrotu środków wydatkowanych na zakup domu, który został nabyty wyłącznie przez pozwaną, oraz wydatkowanych na jego modernizację w okresie, w którym strony wspólnie w nim mieszkały. W pierwszej instancji powód podnosił, że przysporzył pozwanej korzyść

${ }^{29}$ Rozumowanie to w pewnym stopniu nawiązuje do koncepcji unjust factors stanowiącej specyfikę bezpodstawnego wzbogacenia w common law.

302006 SLT (Sh Ct) 117. 
majątkową z uwagi na planowane w przyszłości małżeństwo, które nie doszło do skutku, pozwana wykazała jednak, że ona nigdy nie miała zamiaru zawarcia małżeństwa, a jedynie powód miał takie plany. Ze względu na takie stanowiska stron powstał bardzo istotny problem prawny dotyczący tego, czy podstawa (cau$s a$ ), ze względu na którą nastąpiło świadczenie, musi być uzgodniona przez strony, choćby w sposób dorozumiany (mutual understanding), czy też wystarczy, że zostanie ustalona poprzez odniesienie do stanu świadomości (state of mind) wyłącznie świadczącego. W wyroku sądu I instancji uznano, że uzgodnienie nie jest konieczne. Przed sądem II instancji powód dokonał istotnej modyfikacji swego stanowiska, ponieważ nie twierdził już, że kierował się zawarciem małżeństwa, ale podnosił, iż spełnił swe świadczenia w oczekiwaniu dalszego trwania związku jako partnerskiego. Sheriff Principal uznał, że oczekiwanie kontynuacji związku jako partnerskiego stanowi wystarczającą causa świadczenia, której nieurzeczywistnienie uprawnia do jego zwrotu, i przychylił się do poglądu prawnego sądu I instancji, że mutual undestanding nie jest konieczne dla wyznaczenia causa, lecz wystarcza jednostronne oczekiwanie świadczącego.

W ten sposób sąd II instancji odszedł od poglądu prawnego leżącego u podstaw rozstrzygnięcia w sprawie Grieve v. Morrison ${ }^{31}$, w której Lord Morison uznał, że causa przysporzenia powinna być przez strony uzgodniona, wyraźnie lub w sposób dorozumiany, wynikający z całokształtu okoliczności sprawy (implied from the circumstances). Wymóg uzgodnienia pozwala odróżnić causa od motywu świadczącego, albowiem motyw ma charakter jednostronny i subiektywny, przez co nie jest prawnie relewantny. W sprawie Satchwell v. McIntosh Sheriff Principal uznał jednak, że pogląd ten jest zbyt bliski modelowi kontraktowemu, w jego ocenie odrzuconemu w sprawie Shilliday $v$ Smith.

Uznanie, że świadczenie podlega zwrotowi nie tylko w przypadku, w którym zostało spełnione w oczekiwaniu przyszłego małżeństwa, ale także w oczekiwaniu dalszego trwania związku partnerskiego, zasługuje na aprobatę. Z punktu widzenia przesłanek condictio causa data causa non secuta, tak jak była ona rozumiana $\mathrm{w}$ prawie rzymskim ${ }^{32} \mathrm{i}$ jak jest rozumiana w prawie współczesnym, jedno i drugie zdarzenie może stanowić causa. Planowane małżeństwo o tyle nie budzi wątpliwości, że stanowiło już causa świadczeń spełnianych tytułem posagu w starożytnym Rzymie, przez co stało się klasycznym przykładem causa data. Oczekiwanie dalszego trwania związku partnerskiego jest mniej oczywiste,

311993 SLT 852.

${ }^{32}$ Zob. D.12.4 i C.4.7. Szerzej problematykę rzymskiej condictio causa data causa non secuta podejmuję w monografii Świadczenie w zamierzonym celu, który nie zostat osiagnięty. Studium z prawa rzymskiego, Toruń 2012. 
gdyż nie ma za sobą tak długiej i solidnej tradycji. Niemniej nie widzę powodów, dla których sam charakter związku stron jako związku partnerskiego, odmienny od małżeństwa zasadniczo na płaszczyźnie prawnej, stanowił argument przeciwko uznaniu jego trwania za causa świadczenia. Nie można zatem świadczącego postawić w niekorzystnej sytuacji prawnej tylko dlatego, że nie zamierzał formalizować swojego związku poprzez małżeństwo. Trzeba też zauważyć, że często łatwiej jest wykazywać wolę dalszego pozostawania w związku niż udowadniać, że strony planowały zawrzeć małżeństwo. W sytuacji, w której współczesne społeczeństwo przyjęło, że wspólne pożycie dwojga osób wcale nie musi prowadzić do zawarcia małżeństwa, nie można domniemywać, że strony planowały je zawrzeć. Tym samym stawianie wymogu wykazania takiego zamiaru byłoby w wielu przypadkach trudne na płaszczyźnie dowodowej ${ }^{33}$.

Natomiast pogląd prawny, że causa może zostać wyznaczona jednostronnie budzi poważne wątpliwości. Wydaje się, że Sheriff Principal nadinterpretował pogląd prawny wyrażony w sprawie Shilliday v. Smith, albowiem założenie, że causa świadczenia nie może być przedmiotem kontraktu, aby można było zastosować instytucję bezpodstawnego wzbogacenia, nie oznacza, że nie jest ona w żaden sposób przedmiotem uzgodnienia stron i że może być wyznaczana wyłącznie przez jedną stronę ${ }^{34}$. Uzgodnienia między stronami związków partnerskich nie muszą i często nie mają charakteru czynności prawnej, nawet dokonanej w sposób odformalizowany, wystarczy, że sprowadzają się do tego, iż przyjmującemu świadczenie znana jest przyczyna, ze względu ma którą świadczący zdecydował się je spełnić i że poprzez przyjęcie świadczenia daje wyraz jej aprobaty. Prawo kontynentalne w kontekście condictio causa data causa non secuta operuje pojęciem porozumienia co do podstawy świadczenia, które nie jest czynnością prawną, aczkolwiek nadal stanowi wyraz woli obu stron. Co więcej, akurat zawarcie małżeństwa nie może stanowić przedmiotu zobowiązania wynikającego z umowy, albowiem umowa taka byłaby nieważna ${ }^{35}$. Nie można jednak w ten sam sposób traktować sytuacji, w której przyjmujący świadczenie nie zna przyczyny (celu) świadczenia, uważa, że jest ono spełniane z innej przy-

${ }^{33}$ Nie dotyczy to tak oczywistych sytuacji, jak te, w których strony zaręczyły się lub odwołały już zamówiony ślub, wszakże po pierwsze nie są one częste, po drugie nawet w tych przypadkach zaręczyny lub data ślubu musi pozostawać w takiej korelacji z datą, w której spełniono świadczenia, aby istotnie można było mówić, że świadczenie nastąpiło w oczekiwaniu zawarcia małżeństwa. Tym samym świadczenie odległe czasowo lub spełnione po odwołaniu ślubu nie może być uznane za spełnione w oczekiwaniu zawarcia małżeństwa tylko z tego powodu, że strony w ogóle kiedyś planowały małżeństwo.

${ }^{34}$ Por. R. Evans-Jones, Causes of Action and Remedies in Unjustified Enrichment: Satchwell vMcIntosh, „Edinburgh Law Review“ 2007, v. 11, s. 107.

35 Ibidem. 
czyny (innym celu) lub też ujawnił świadczącemu swą wolę odmienną od motywacji świadczącego, w szczególności dał mu do zrozumienia, że nie traktuje ich relacji jako stałego związku. Wydaje się przy tym, że świadczenia majątkowe o dużej wartości, w dodatku spełniane w okolicznościach, które wskazują na to, że miały na względzie dobro związku (np. kupno lub remont wspólnie zajmowanej nieruchomości), co do zasady mają charakter causa, której nieosiągnięcie uprawnia do żądania zwrotu. Wniosek odmienny oczywiście jest in casu możliwy, jednakże powinien być solidnie umotywowany.

V. Kolejnym istotnym orzeczeniem Court of Session jest wyrok Izby Wyższej (Inner House) w sprawie Thomson v. Mooney z 2013 r., w której głównym problem prawnym nie była podstawa żądania powoda, ale podniesiony przez pozwaną zarzut upływu pięcioletniego terminu przedawnienia ${ }^{36}$. Skuteczność tego zarzutu zależała od oceny, kiedy pozwana stała się bezpodstawnie wzbogacona. Strony pozostawały w nieformalnym związku, a w 2005 r. zaręczyły się dając w ten sposób wyraz zamiarowi zawarcia małżeństwa. W czerwcu tego samego roku kupiły dom, który stał się przedmiotem ich współwłasności w równych udziałach po $1 / 2$, choć zakup został sfinansowany wyłącznie ze środków powoda. We wrześniu 2007 r. związek stron rozpadł się, przez co planowane małżeństwo nie zostało zawarte. W pozwie o zapłatę połowy środków wydatkowanych na zakup domu powód wprost podał, że jego świadczenie nastąpiło na tej podstawie, że strony zamierzały zawrzeć związek małżeński i sam zakup nastąpił in contemplation of that event, skoro zaś zdarzenie to nie miało miejsca pozwana stała się bezpodstawnie wzbogacona. Nie ulegało też wątpliwości, że strony nie zawarły umowy uzasadniającej potraktowanie środków przekazanych przez powoda jako pożyczki udzielonej pozwanej.

Pozwana nie kwestionowała podstaw roszczenia powoda, jednakże podniosła zarzut jego przedawnienia, stwierdzając, że roszczenie to stało się wymagalne już w chwili zakupu domu, tj. w czerwcu 2005 r., zatem pięcioletni termin przedawnienia zdążył już upłynąć zanim powód wniósł, w 2011 r., pozew. Z kolei powód podnosił, że jego roszczenie stało się wymagalne dopiero po zerwaniu związku i ustaniu zamiaru zawarcia małżeństwa w 2007 r. Samo wzbogacenie pozwanej nastąpiło, co prawda, w 2005 r., jednakże dopiero po zerwaniu związku stało się ono bezpodstawne.

Court of Session nie miał wątpliwości, że roszczenie powoda stanowi przykład roszczenia z bezpodstawnego wzbogacenia, określany zwykle rzymskim terminem condictio causa data causa non secuta. W uzasadnieniu opinii Lorda Eassie została przywołana zarówno sprawa Shilliday v. Smith, jak i cytowany

36 Termin ten wynikał z Praescription and Limitation Act z 1973 r. 
wyżej fragment Instytucji Staira. W oparciu o treść tego fragmentu Lord rozstrzygnął problem prawny dotyczący terminu wymagalności roszczenia opartego na tej kondykcji, stwierdzając, że jeżeli wzbogacenie nastąpiło z uwagi na oczekiwane przyszłe zdarzenie, jednakże zdarzenie to nie nastąpiło, to właśnie ta okoliczność, że zdarzenie to nie nastąpiło, powoduje powstanie roszczenia o zwrot wzbogacenia. Tak długo zaś, jak causa, ze względu na którą doszło do wzbogacenia, pozostaje lub nadal ma nastąpić (is still in contemplation or still to be provided) nie można uznać, że wzbogacenie ma charakter sine causa, wobec czego nie można uznać, że jest nieusprawiedliwione (unjustified).

Lord Eassie skrytykował także wyrażony w niższej instancji pogląd Lorda Drummond Younga w wyroku Izby Niższej Court of Session (Outer House) ${ }^{37}$, według którego wzbogacenie miało taki charakter już od samego początku i że pozwana nie miała podstawy prawnej zachować otrzymaną korzyść nawet w czasie, w którym strony oczekiwały na zawarcie małżeństwa. Co interesujące, opierając się na powyższym cytacie z Instytucji Staira Lord Drummond Young postawił tezę, że w przypadku świadczeń na poczet małżeństwa, które ma zostać w przyszłości zawarte nie zachodzi podstawa usprawiedliwiająca zachowanie takiego świadczenia już od chwili, w której zostało ono spełnione. Jeżeli zaś małżeństwo dojdzie do skutku świadczenie takie staje się darowizną, co wszakże nie ma wpływu na jego pierwotny charakter. Lord Eassie stanowczo odrzucił tę argumentację, stwierdzając, że jeżeli uznać by świadczenie powoda za darowiznę, to należałoby uczynić wyjątek od zasady braku zwrotu otrzymanej darowizny w tych sytuacjach, w których darowizna następuje ze względu na oczekiwane zdarzenie przyszłe, które jednak nie dochodzi do skutku, np. na poczet planowanego małżeństwa. W takim jednak przypadku obowiązek zwrotu darowizny powstaje dopiero po tym, jak to przyszłe zdarzenie nie nastąpiło, wcześniej bowiem obdarowany jest uprawniony do zachowania jej. Pogląd ten Lord Eassie umotywował szerszym odniesieniem do koncepcji bezpodstawnego wzbogacenia w orzecznictwie szkockim ${ }^{38}$, uznając, że zobowiązanie do zwrotu bezpodstawnego wzbogacenia powstaje w wielu przeróżnych sytuacjach, w niektórych wzbogacenie jest nieusprawiedliwione od samego początku, ale w innych staje się takie później, jeżeli zajdzie okoliczność usuwająca początkową podstawę (initial justification) wzbogacenia.

Powyższa argumentacja Sądu II instancji jest zasadniczo spójna z orzecznictwem kontynentalnym, które wiąże powstanie roszczenia o zwrot świadcze-

37 Zob. Opinia Lorda Drummond Younga, Outer House 2012, CSOH 177, A177/11.

${ }^{38}$ Wprost została przywołana sprawa Dollar Land (Cumbernauld) Ltd v. CIN Properties Ltd 1996 SC 331. 
nia dopiero $\mathrm{z}$ chwilą, $\mathrm{w}$ której cel świadczenia nie został osiągnięty, a nie już z chwilą spełnienia świadczenia ${ }^{39}$. Tę generalną zasadę dotyczącą świadczeń spełnianych $o b$ rem należy stosować także w odniesieniu do związków partnerskich, albowiem dopiero z chwilą ustania związku okazuje się, że cel świadczenia nie został osiągnięty, bez znaczenia przy tym jest, czy świadczący kierował się zamiarem zawarcia małżeństwa, czy też liczył na dalsze trwanie związku nieformalnego. W trakcie trwania związku wzbogacenie uzyskane przez partnera nie staje się jeszcze bezpodstawne. Przyjęcie tej wykładni łączy się w praktyce z tą dodatkową trudnością, że często trudno wskazać choćby w przybliżeniu datę, w której związek się rozpadł, gdyż proces ten może być rozciągnięty w czasie. Z kolei data świadczenia jest z reguły bardziej uchwytna. Okoliczność ta nie stanowi jednak argumentu za zmianą wykładni i odejściem od przesłanek konstrukcyjnych relewantnej kondykcji, może jednak stanowić argument za przyjęciem korzystniejszej dla powoda oceny okoliczności faktycznych wskazujących na czas zerwania związku.

VI. Z czasem koncepcja, aby to bezpodstawne wzbogacenie stało się instrumentem rozliczenia świadczeń spełnionych przez stronę nieformalnego związku na rzecz jej partnera, została poddana w Szkocji krytyce i to z wielu powodów. Przede wszystkim podnoszono trudności dowodowe, które musi pokonać powód żądający zwrotu świadczenia na tej podstawie. Samą koncepcję bezpodstawnego wzbogacenia uznano za zbyt niejasną i skomplikowaną. Poza tym bezpodstawne wzbogacenie uniemożliwia uwzględnienie świadczeń o charakterze niemajątkowym, które często stanowią część więzi łączącej partnerów. Argumenty te stały się jedną z przyczyn decyzji o ustawowej regulacji omawianej materii.

Pomimo rozbudowanej regulacji zawartej w Family Law (Scotland) Act z 2006 r. w praktyce powodowie nadal jako podstawę prawną żądania przywołują bezpodstawne wzbogacenie, zwykle obok przepisów ustawy. Przykładem tego jest sprawa Harley v. Robertson z 2011 r., także dotycząca wzbogacenia wynikłego z przyrostu wartości nieruchomości wskutek remontu ${ }^{40}$. Sheriff C. Caldwell poświęcił w niej sporo miejsca wzajemnemu stosunkowi regulacji ustawowej i bezpodstawnego wzbogacenia, opowiadając się za tym, że w zakresie swej regulacji wyłączne zastosowanie ma ustawa, niemniej zauważył, że regulacja ta nie jest wyczerpująca i pozostawia pewne pole na stosowanie zasad bezpodstawnego wzbogacenia ${ }^{41}$. W tym konkretnym przypadku nie było

39 Zob. wyroki SN: z 30.01.2004 r., I CK 129/03; z 25.03.2004 r., II CK 116/03; z 8.03.2007 r., III CZP 3/07; postanowienie SN z 14.06.2016 r., II CSK 828/15.

${ }^{40}$ Wyrok z 9.12.2011 r., sprawa o sygn. akt A 41/11, dostępna poprzez wyszukiwarkę na stronie www.scotcourts.gov.uk.

${ }^{41}$ Także w literaturze podkreśla się, że bezpodstawne wzbogacenie nadal w pewnym zakre- 
jednak potrzeby dokonywać szczegółowej analizy, czy roszczenie powódki nie jest objęte przepisami ustawy i wobec tego można je oprzeć na bezpodstawnym wzbogaceniu, albowiem Sąd uznał, że nie są spełnione podstawowe przesłanki umożliwiające wywodzenie jakichkolwiek roszczeń z bezpodstawnego wzbogacenia. Taką przesłanką jest bowiem istnienie causa, ze względu na którą nastąpiło wzbogacenie i może być nią zarówno zamiar zawarcia w przyszłości związku małżeńskiego, jak i zamiar dalszej kontynuacji związku jako partnerskiego. W tym przypadku jednak, mimo deklaracji powódki, iż oczekiwała, że będzie zamieszkiwać na stałe w domu pozwanego i że strony rozważały zawarcie małżeństwa, Sąd uznał, iż nie ma takiej causa. Strony w rzeczywistości w okresie remontu domu pozwanego nie planowały zawarcia małżeństwa. Świadczy o tym fakt, że ich związek był burzliwy, kilkakrotnie przejściowo zrywany, powódka planowała nawet małżeństwo z innym mężczyzną, strony nigdy nie ustaliły daty zawarcia małżeństwa ani nie były zaręczone. Pozwany przyznał co prawda, że strony rozważały małżeństwo, ale było to kilka lat przed remontem. Podobne względy, a zwłaszcza liczne i długotrwałe przerwy we wspólnym pożyciu, inne związki powódki i stanowiące poważny problem i przyczynę częstych rozstań skłonności alkoholowe pozwanego, skłoniły Sąd do wniosku, że powódka nie miała prawa oczekiwać, iż będzie na stałe zamieszkiwać w wyremontowanym domu pozwanego, żyjąc z pozwanym in family. Nic też nie wskazywało na to, że stan taki miałby się w przyszłości zmienić.

Sprawa ta jest istotna $\mathrm{z}$ co najmniej dwóch zasadniczych przyczyn. Po pierwsze, obrazuje, że nawet istnienie regulacji ustawowej nie wyklucza potrzeby i możliwości wywodzenia roszczeń z bezpodstawnego wzbogacenia, co świadczy także o tym, iż bardzo trudno jest wyczerpująco uregulować wszystkie możliwe stany faktyczne i roszczenia stron po ustaniu związku. Trzeba się jednak zgodzić, że relewantne przepisy ustawy będą wyprzedzały reżim bezpodstawnego wzbogacenia, który może mieć co najwyżej zastosowanie w zasadzie wyjątkowe (zależy to od stopnia kompleksowości ustawy). Po drugie, samo istnienie causa, ze względu na którą nastąpiło świadczenie, może stanowić kwestię bardzo ocenną i zależną od szczegółowego rozważenia całokształtu okoliczności faktycznych sprawy. Dość łatwo powodowi podnosić, że świadczył coś w oczekiwaniu dalszego trwania związku, jednakże należy rozważyć, czy rzeczywiście

sie będzie podstawą rozstrzygnięć sądów, choćby dlatego, że ustawa nie wyklucza tej podstawy, nadto będzie ona stosowana zwłaszcza w odniesieniu do związków, które nie mieszczą się w definicji ustawowej, związków, w których strony żyją wspólnie, ale nie jako mąż i żona lub civil partners, roszczeń przedawnionych na podstawie przepisów ustawy, zwrotu wydatków poniesionych przez narzeczonych na planowany ślub, który został odwołany (zob. szerzej Q. MacQeen, Unjustified Enrichment and Family Law, ,Edinburgh Law School Working Papers” 2010, no. 01, s. 4 i n.). 
powód kierował się taką motywacją i czy w danych okolicznościach takie oczekiwanie było rozsądne i usprawiedliwione. In casu można podnieść poważne argumenty przeciwko takiemu stanowisku powoda, zwykle jednak nie będą to argumenty jednoznacznie przekonujące i będą pozostawiały sporo miejsca na uznanie sądu.

VII. Przedstawione powyżej orzecznictwo sądów szkockich dowodzi, że condictio ob rem dati jest użyteczna jako instrument rozliczenia świadczeń spełnianych przez partnerów. Nie jest to jednak instrument doskonały, co przesądziło o potrzebie stworzenia regulacji ustawowej, w założeniu lepiej dostosowanej do skomplikowanego charakteru relacji, zarówno majątkowych, jak i niemajątkowych, łączących strony, a także łatwiejszej w zastosowaniu ${ }^{42}$. Warto także zauważyć, że wszystkie wzmiankowane powyżej sprawy odnosiły się do świadczeń doniosłych co do charakteru i wysokości, albowiem stałym schematem był w nich udział w zakupie lub remoncie nieruchomości partnera, wspólnie zajmowanej przez strony w trakcie trwania związku. Stanowi to zatem wskazówkę, że relewantna kondykcja nie służy zwrotowi zwykłych, codziennych świadczeń spełnianych przez partnerów dla dobra związku, co do zasady zresztą wynikających z choćby dorozumianych uzgodnień stron, w tym zwłaszcza uzgodnień dotyczących ich ról oraz podziału obowiązków. Trudno zaś na tej samej płaszczyźnie stawiać roszczenie o zwrot kosztów utrzymania partnera zwłaszcza, jeżeli jego wkład w związek polegał na trosce o wspólne gospodarstwo domowe, wychowaniu dzieci, załatwianiu bieżących spraw, organizowaniu wypoczynku itp. Doświadczenia sądów szkockich uczą jednak, że dopóki polski ustawodawca nie zdecyduje się na uregulowanie związków partnerskich w ustawie, dopóty polskie sądy będą musiały stosować instrumenty prawne, które tylko po części odpowiadają specyfice tej materii. Każdy instrument, na czele ze wzmiankowaną kondykcją, musi być stosowany w sposób elastyczny, dostosowany do okoliczności konkretnej sprawy.

Orzecznictwo sądów szkockich stanowi także argument przeciwko wzmiankowanej we wstępie wyrażonej w polskiej doktrynie krytyce zastosowania relewantnej kondykcji w stosunkach między stronami związków partnerskich (konkubentami). Nie można zgodzić się z tezą, że związek taki nie powinien być normowany przepisami prawa, albowiem sam odmienny od małżeństwa jego charakter nie oznacza, że nie poddaje się regulacji prawnej ani nawet nie potrze-

${ }^{42}$ Ten aspekt także jest podkreślany w literaturze, głównie ze względu na dość skomplikowany obraz instytucji bezpodstawnego wzbogacenia (H. MacQeen, op. cit., s. 4 i n.). W Polsce sytuacja jest lepsza o tyle, że bezpodstawne wzbogacenie jest uregulowane w przepisach kodeksu jako jedno z podstawowych źródeł zobowiązań, choć poprawne stosowanie tych przepisów wymaga znajomości koncepcji teoretycznych, które się za nimi kryją. 
buje takiej regulacji. Doświadczenia zarówno polskie, jak i szkockie, wskazują na potrzebę regulacji prawnej związku partnerskiego w pewnym zakresie, bez konieczności zrównywania go z małżeństwem. Zakres ten obejmuje zwłaszcza skutki prawne ustania związku, czy to wskutek zerwania czy to śmierci jednej ze stron. W dyskrecji ustawodawcy pozostaje zaś, czy stworzy specjalną ku temu regulację, czy pozostawi sądom stosowanie istniejących już instrumentów prawnych.

Przeciwko zastosowaniu kondykcji nie przemawia okoliczność, że strony nie mogą skutecznie zobowiązać się, że będą kontynuowały związek lub sformalizują go zawierając małżeństwo. Podzielam wprawdzie stanowisko, że nie można zawrzeć ważnej umowy zobowiązującej do zawarcia małżeństwa lub kontynuacji związku, jednakże w niniejszym przypadku strony takiej umowy nie zawierają. Krytycy kondykcji zdają się nie zauważać, że wymagane porozumienie co do podstawy prawnej świadczenia w ogóle nie jest czynnością prawną, nie stanowi kontraktu, co podkreślono zwłaszcza w sprawie Shilliday v. Smith, tym samym nie rodzi prawnie wiążących zobowiązań stron, lecz wyznacza jedynie, aby cel świadczenia był znany i aprobowany przez jego odbiorcę. Cel świadczenia poddaje się ocenie zarówno z punktu widzenia zgodności z prawem, jak i z dobrymi obyczajami ${ }^{43}$, co nie przemawia jednak przeciwko możliwości zastosowania kondykcji, przede wszystkim dlatego, że stanowiące ten cel oczekiwanie dalszego trwania związku nie jest tym samym, co zobowiązanie się stron do kontynuacji związku. Należy tu dostrzec dość subtelną różnicę między celem świadczenia objętym porozumieniem co do podstawy świadczenia, a zobowiązaniem się stron wynikającym z umowy, której najlepszą ilustrację jest sprawa Shilliday. Tylko w tym drugim przypadku można przyjąć konstrukcję nieważności umowy, natomiast w pierwszym taki cel świadczenia nie narusza prawa ani nie jest naganny moralnie, chyba że przeciwny wniosek uzasadniają szczególne okoliczności ${ }^{44}$.

43 Świadczy o tym rzymska condictio ob turpem causam (D.12.5) i współczesna koncepcja świadczenia niegodziwego (art. 412 k.c.).

${ }^{44}$ Mam tu na myśli dyskusję toczącą się na kanwie wyroku Sądu Najwyższego z 12.01.2006, II CK 342/2005, dotyczącego świadczeń na rzecz utrzymanki, ponieważ w szczególnych okolicznościach tej sprawy istotnie można było rozważać czy świadczenia te były niegodziwe (co wszakże, moim zdaniem, nie było oczywiste). Zob. glosy do tego orzeczenia P. Księżaka, ,Monitor Prawniczy” 2008, nr 10, s. 574 i n.; M. Gutowskiego, „Palestra” 2008, z. 1-2, s. 288 i n. oraz komentarz T. Sokołowskiego, Kodeks, uwaga 8 do art. 410. 


\section{BIBLIOGRAFIA:}

Carey-Miller D.L., Combe M.M., The Boundaries of Property Rights in Scots Law, Report to the XVIIth International Congress of Comparative Law, July 2006, „Electronic Journal of Comparative Law" 2006, vol. 10.3.

Dubis W., Kodeks cywilny. Komentarz, red. E. Gniewek, Warszawa 2016.

Evans-Jones R., Causes of Action and Remedies in Unjustified Enrichment: Satchwell vMcIntosh, „Edinburgh Law Review” 2007, vol. 11 (1).

Hartwich F., Związki partnerskie. Aspekty prawne, Warszawa 2011.

Hogg M.A., Lowlands to Low Country. Perspectives on the Scottish and Dutch Law of Unjustified Enrichment, „Ius Commune Lectures on European Private Law” 2001, nr 3.

Gutowski M., Glosa do wyroku Sądu Najwyższego z 12 stycznia 2006 r., II CK 342/2005, „Palestra” 2008, z. 1-2.

Ignatowicz J., Nazar M., Prawo rodzinne, Warszawa 2012.

Karaszewski G., [w:] Kodeks cywilny. Komentarz, red. J. Ciszewski, Warszawa 2014.

Kołakowski K., [w:] Kodeks. cywilny. Księga trzecia. Zobowiazania, Komentarz, red. G. Bieniek, Warszawa 2011.

Księżak P., Bezpodstawne wzbogacenie. Art. 405-414 KC. Komentarz, Warszawa 2007. Księżak P., Glosa do wyroku Sądu Najwyższego z 12 stycznia 2006 r., II CK 342/2005, „Monitor Prawniczy” 2008, nr 10, s. 574-576.

Księżak P., [w:] Kodeks cywilny. Komentarz, red. K. Osajda, Warszawa 2016.

Łętowska E., Bezpodstawne wzbogacenie, Warszawa 2000.

Macqueen H., Payment of Another's Debt, [in:] Unjustified Enrichment: Key Issues in Comparative Perspective, eds. R. Zimmermann and D. Johnston, Cambridge 2002. Macqueen H., Unjustified Enrichment and Family Law, „Edinburgh Law School Working Papers" 2010, nr 1.

Mostowik P., Bezpodstawne wzbogacenie, „Studia Prawa Prywatnego” 2007, z. 2(5).

Mostowik P., Bezpodstawne wzbogacenie, [w:] System Prawa Prywatnego, t. 6. Zobowiazania. Część Ogólna, Warszawa 2009.

Mularski K., [w:] Kodeks Cywilny. Tom 1, Komentarz do art. 1-449 ${ }^{11}$, red. M. Gutowski, Warszawa 2016.

Nazar M., Konkubinat, [w:] System Prawa Prywatnego, t. 11, Prawo rodzinne i opiekuńcze, red. T. Smyczyński, Warszawa 2009.

Ohanowicz A., Niestuszne wzbogacenie, [w:] A. Ohanowicz, Wybór prac, red. A. Gulczyńskiego, Warszawa 2007.

Pawliczak J., Szkocki model regulacji konkubinatu, „Kwartalnik Prawa Prywatnego” 2010, z. 3.

Pawliczak J., Zarejestrowany związek partnerski a małżeństwo, Warszawa 2014. 
Du Plessis J., Towards a Rational Structure of Liability for Unjustified Enrichment: Thoughts from Two Mixes Jurisdiction, [in:] Grundstrukturen Eines Bereicherungsrechts, ed. R. Zimmermann, Tübingen 2005.

Rzetecka-Gil A., Kodeks Cywilny. Komentarz, Zobowiązania-Czesśc Ogólna, Warszawa 2011.

Serda W., Nienależne świadczenie, Warszawa 1988.

Sobczyk M., Świadczenie $w$ zamierzonym celu, który nie został osiągnięty. Studium z prawa rzymskiego, Toruń 2012.

Sobczyk M., Rozliczenia między stronami związków partnerskich na podstawie przepisów o bezpodstawnym wzbogaceniu, „Kwartalnik Prawa Prywatnego” 2015, nr 2.

Sokołowski T., Kodeks Cywilny. Komentarz, red. A. Kidyba, Warszawa 2014.

Szlęzak A., Stosunki majątkowe między konkubentami. Zagadnienia wybrane, Poznań 1992.

Trzaskowski R., Kodeks Cywilny. Komentarz, red. J. Gudowski, Warszawa 2013.

Whitty N.R., Rationality, Nationality and the Taxonomy of Unjustified Enrichment, [in:] Unjustified Enrichment: Key Issues in Comparative Perspective, eds. R. Zimmermann and D. Johnston, Cambridge 2002.

Wolffe J., Enrichment by Improvements in Scots Law, [in:] Unjustified Enrichment: Key Issues in Comparative Perspective, eds. R. Zimmermann and D. Johnston, Cambridge 2002 . 
